\title{
OBRIGAÇÕES FISCAIS DE EXPATRIADOS NO BRASIL E DE BRASILEIROS NO EXTERIOR
}

\author{
Melissa Resende Grassi de Lima ${ }^{1}$ \\ Adem Bafti ${ }^{2}$ \\ Tomaz Antônio Martucci Valim Balthazar ${ }^{3}$
}

Resumo: O Direito Tributário Internacional é o ramo do Direito que regulamenta as obrigações fiscais de residentes e não residentes em nosso País, relacionado à renda auferida de fonte brasileira e estrangeira, a acordos para reciprocidade de tratamento e para evitar a bitributação, e garantir ao cidadão que não seja tributado de forma irregular e prejudicial. Serão abordados conceitos e aplicabilidade destas modalidades, definindo suas principais características, explicando as peculiaridades e diferenças. Os procedimentos metodológicos utilizados foram: legislação vigente, doutrina e artigos científicos. O objetivo é mostrar a real importância de tais obrigações e descomplicá-las para se tornarem acessíveis à população.

Palavras-chave: Direito Tributário Internacional; Expatriados; Obrigações tributárias; Residência fiscal; Globalização.

\footnotetext{
${ }^{1}$ Direito/Universidade do Vale do Paraíba, Brasil. E-mail: melissaresende@icloud.com.

2 Direito/Universidade do Vale do Paraíba, Brasil. E-mail: bafti@babo.adv.br.

${ }^{3}$ Direito/Pontifícia Universidade Católica, Brasil. E-mail: tomaz.balthazar@pwc.com.
} 